\title{
Innovation in batik tulis with ICT technology for sustainability design
}

\author{
F. Abdullah \\ Universitas Pendidikan Indonesia, Bandung, Indonesia \\ B.T. Wardoyo* \\ Universitas Trisakti, Jakarta, Indonesia
}

A.M. Adnan

University Technology of Mara, Selangor, Malaysia

\begin{abstract}
The development of ICT technology (Information and Communication Technology) is currently very rapid, creating tools to support human life. Information and communication technology are devices consisting of hardware, software, processes, and systems used to help the communication process between humans be successful. The problem in creating batik tulis clothing is that there have not been many collaborations with ICT technology so far. Both ICT technology and the creation of batik tulis are still running, respectively. On the other hand, today's human needs for clothing are not limited to body coverings and fashion but also develop as a means of security, communication, and data storage. The method used in this paper is qualitative-experimental using the design creation stage. The finding of this creation is that human needs for batik are also increasing; it is necessary to create a creation that combines ICT technology and batik tulis to answer human needs in the era of 4.0. This creation can be a solution to human needs for security, communication, and data storage that is integrated into a batik tulis cloth.
\end{abstract}

Keywords: batik tulis, ICT, sustainability design

\section{INTRODUCTION}

The industrial revolution 4.0 is part of globalization. The era of Industrial Revolution 4.0 has fundamentally caused many changes way of thinking of humanity, including the way of life and the way of relating one human being to another. Era 4.0 has disrupted all human activities in various aspects of life, not only in technology but also in the economic, social, and political fields (Prasetyo \& Trisyanti 2018). Globalization then entered a new stage through the paradigm of The Fourth Industrial Revolution, which states that the world has entered four phases of the revolution, namely: (1) Industrial Revolution 1.0 through the invention of the steam engine in the 18th century; (2) Industrial Revolution 2.0 in the form of electricity usage in the 19th century; (3) Industrial Revolution 3.0 in the form of computerization in the 1970s, and; (4) Industrial Revolution 4.0 through artificial intelligence engineering and IoT (Internet of Things) as the backbone of human-machine progress and connectivity (Schwab 2017).

The rapid progress of ICT (Information and Communication Technology) in the Industrial Revolution 4.0 era has changed the face of the world with the consequences that followed. The era of the Industrial Revolution 4.0 in the form of sophisticated information and communication technology has encouraged the exchange of information and communication very quickly without the constraints of time and space boundaries (Dryden \& Voss 1999). The Agency for Science and

\footnotetext{
*Corresponding author: bambangtri@trisakti.ac.id
} 
Culture of the Nations (UNESCO) in 2002 stated that the integration of ICT into the world of education, especially into the human learning process, has three main objectives, namely: (1) to build knowledge-based community behavior (knowledge-based society habits); (2) to develop ICT literacy skills; (3) to increase the effectiveness and efficiency of the learning process (Mawardi 2012). UNESCO's support explains the stronger push for ICT integration into other cultural artifacts, including batik.

The use of ICT for collaboration in conventional batik products is currently still minimal. For this reason, human creativity is needed to collaborate with technology and batik fashion traditions. Creativity can be defined as an individual's capacity to develop ideas based on divergent ways of thinking, which is higher than convergent ways of thinking. Creativity can also be interpreted as how an individual is more concerned with solving problems in the real-world context (Basadur $\&$ Gelade 2014). The creative process in terms of answering a problem (problem solver) and this utilization process produces prototypes that can be worn by a broad audience.

Batik artifacts are often positioned as traditional products produced by local craftsmen but become the cultural image of a nation. Batik tulis also faces the threat of mass production from printed (filter print) fabrics claiming to be batik. The existence of batik tulis in aesthetics and commercial art is part of the demand and supply conditions in the market. Various cultural protections, in this case, batik motifs, have been carried out, including learning local content in schools even though the implementation of batik as cultural learning is carried out unevenly in various regions in Indonesia (Farid 2012). This makes Batik protection very critical from an industrial perspective. Poon's research results found that mass-produced batik is required to be adaptive to current clothing needs (Poon 2017).

Batik tulis clothing is closely related to the characteristics of the user. In general, the users of batik tulis are a certain level of society (generally the upper economy), have excellent economic capacity, and need products that elevate their personality. According to Gaspersz's (2002) research, several aspects need to be considered to achieve product quality that satisfies users. These aspects include: (1) Performance is a function or use; (2) Additional characteristics or features, namely secondary or complementary characteristics; (3) reliability (reliability); (4) Compliance with specifications; (5) Durability; (6) Convenience (serviceability); and (7) Aesthetics (Gaspersz 2002, in Mandegani et al. 2018). Then a piece of batik is also required to be adaptive to user satisfaction, especially batik tulis users and the phenomenon of the Industrial Revolution 4.0. This paper seeks to investigate to what extent is the collaborative adaptive ability between the batik tradition and the ICT technology.

\section{METHODS}

The creation process to utilize ICT in creative batik in this era of 4.0 used a descriptive - experimental approach. Experimental creation research provides an opportunity for designers not to be confined to a social research framework because knowledge in academia is the knowledge that comes from practical experiences carried out by the creator (Murwanti 2016). The initial stage in utilizing ICT is identifying needs, then the definition of needs is carried out, followed by ideas that can be poured out, then making a prototype (Figure 1).

In the process (Figure 1), there are several parts to definite identification, namely what aspects of the research object's problem. At the definition stage, which is the stage of narrowing down the goals of creating ICT use. The ideas stage is when the design process finds new ideas. Likewise, at

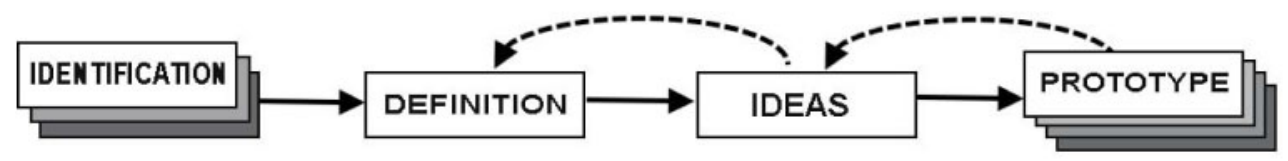

Figure 1. Stages of the ICT utilization process. 
the prototype stage, namely making modeling, final predesign. Henceforth, Figureure 1 is presented in the discussion.

\section{RESULTS AND DISCUSSION}

Batik was chosen in the creation of prototypes because it is inherent in Indonesian culture. Batik has been designated as an intangible cultural heritage from Indonesia by UNESCO since October 2, 2009 (Iedarwati 2017; Kharismawati 2017). The variants of batik motifs in objects as inventions are very diverse, including gifts or souvenirs, even though they are not yet the leading choice for Japanese people to make batik as souvenirs (Kharismawati 2017). This is a challenge for batik to provide added value in its use. In this prototype, a batik motif inherent as a characteristic of Indonesian regions will be selected, namely, the upper clothing, which is attached to its function, namely as body armor, but this top clothing is often used as a gift souvenir.

In the prototype selection, the Mega Mendung motif was chosen, which is the hallmark of Batik Cirebon, West Java. This motif is a cloud shape. This motif is very familiar as a characteristic of the West Java motif, which symbolizes the seven soil layers. This batik is batik in the coastal areas of Indonesia so that the cloud line motifs are more masculine and suitable for use in men's batik, although in the future, this prototype can be widely used in women's clothing.

The use of technology, in this case, is inspired by a series of current works that cannot be separated in various technologies ranging from smartphones, power banks, data storage (data storage) so that these three objects have become objects that cannot be separated or attached to the context of everyday life. Various professions, especially men, will not be separated in these three objects and even work with these objects. It is not surprising that the creation of batik is attached to the various technologies that humans use in their work today. Of course, the character of the technology is simple and easy to put back on so that technology devices can be removed and put on different clothes like the clothes we know today. The design stages are as follows:

The initial stage in the creation process is identification (Figure 1). At this stage, identification of the problems that exist in the creation of batik so far is carried out. Obtained identification of batik tulis products so far is still a lack of collaboration in utilizing the ICT in batik tulis clothing products. In addition, departing from the user aspect, especially batik with high economic value, is still often troublesome by various technologies that must be handheld users in every activity such as smartphones, power storage, and storage data. Identification also shows that users also need a sense of security when doing activities, so technology such as a location scanner (Global Positioning System) can be applied to create batik.

The next stage is the definition, namely the determination of the purpose of creation. The definition at this stage is to create the use of ICT that can support users in the documentation, data storage, security, and communication. The definition of giving added value is the combination of ICT with batik tulis clothing. The definition includes the possibility of creating a batik tulis product that can create novelty for local artisans. It is hoped that this novelty will be able to revive and increase local batikraftsmen's productivity. The third stage is an idea or idea, which generates ideas that can be done by utilizing current ICT technology. The idea offered is the use of combining ICT in batik. This stage of the idea also adapts to the ability of batik to store ICT devices.

In the design sketch (Figure 2) above, there is an idea that creates the prototype. As with batik tulis in general, the batik clothes above are designed for specific uses, not everyday use. It is also necessary to consider the ease of removing ICT devices when washing or dry cleaning is done, so Velcro adhesive rubber can be used to attach ICT technology to the batik clothing. The treatment of batik tulis itself requires special treatment that distinguishes it from ordinary clothing made from printing.

The final stage of this creation process is a prototype. The prototype or archetype is the first form and can also be called the initial form. In design, prototypes are made before being developed into a final product or as part of development before being mass-produced. The prototype stage is an essential activity in the process of creating new products. The purpose of the prototype is 


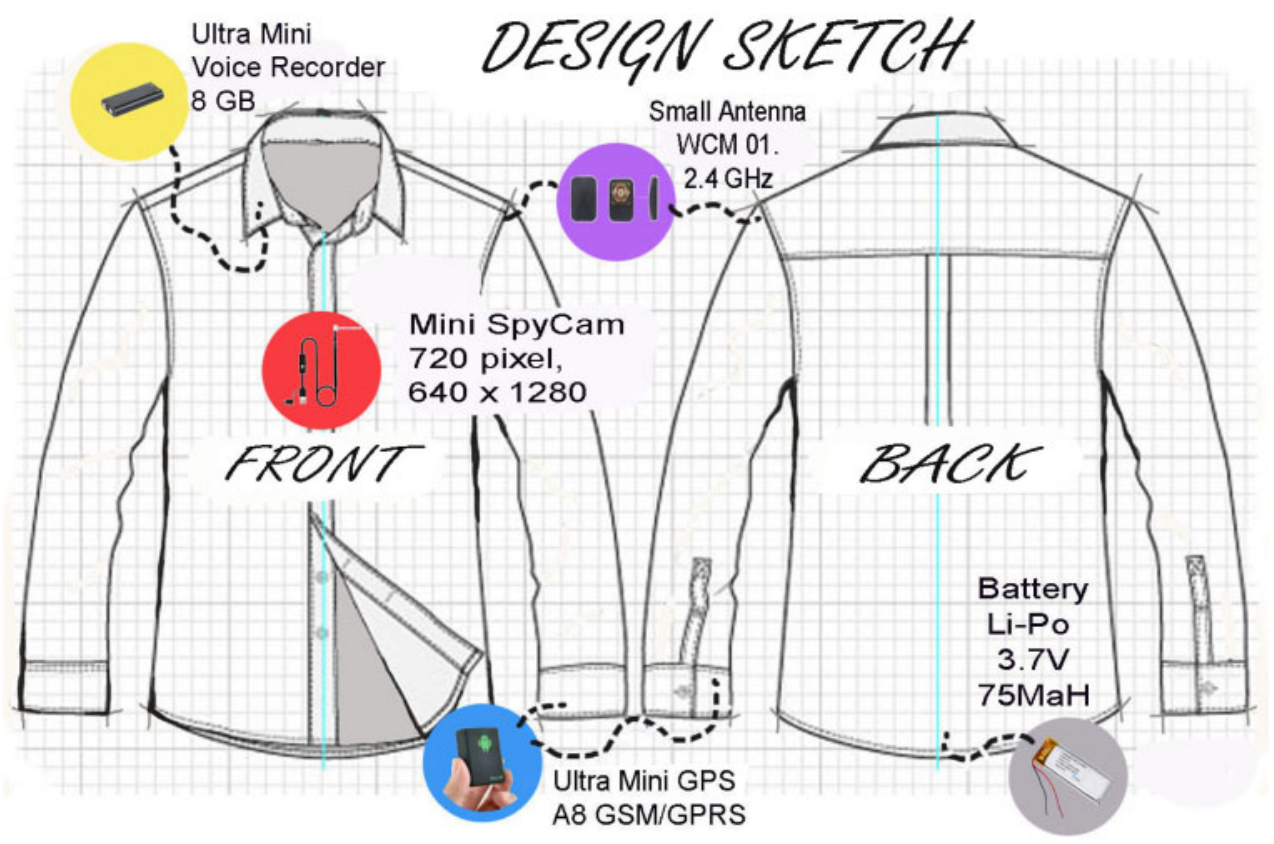

Figure 2. Design sketch as an initial design idea.

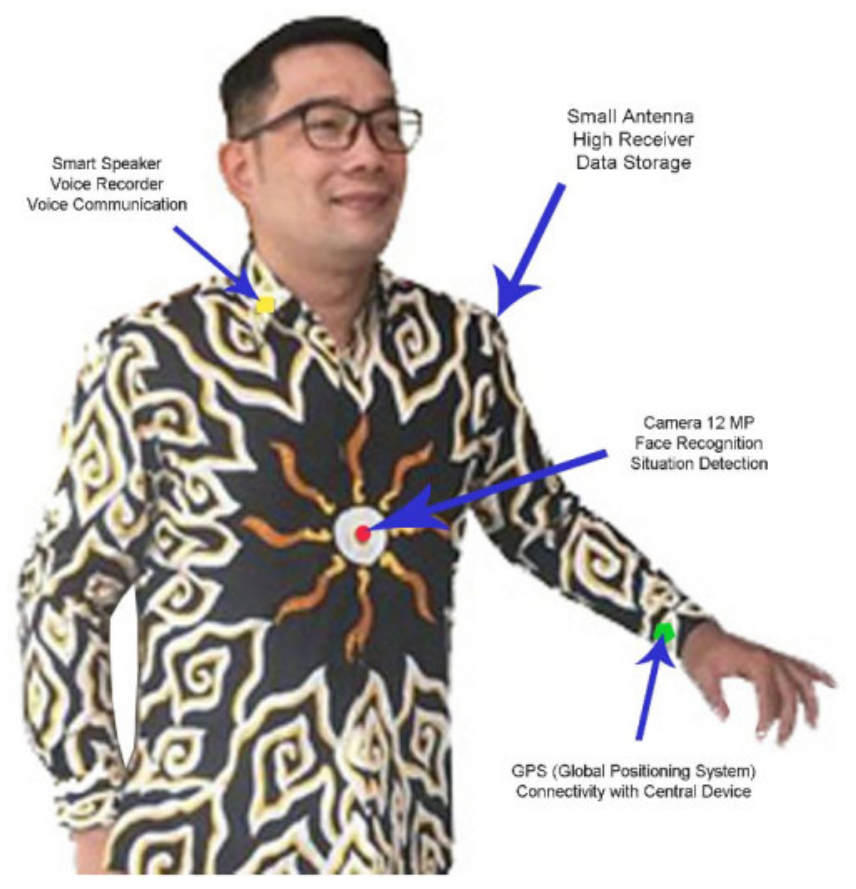

Figure 3. The prototype of using ICT in batik tulis. 
to explore new possibilities or answer pre-existing problems (Elverum et al. 2016). The prototype stage is an essential part of the process of utilizing ICT in batik tulis clothing.

In this utilization process, it is also very possible for sustainable design to occur, from prototypes to ideas, likewise, from the idea stage back to redefinition. This reprocessing process aims to improve the use of ICT in written batik as part of product improvement.

Figure 3 portrays a prototype using ICT in batik tulis clothing. As with other prototypes, there are other alternatives, especially in batik motifs and embedded ICT technology. The incorporation of ICT technology in batik tulis clothing can adapt to the user's different and situational needs.

\section{CONCLUSION}

The progress of the times and technology at this time is speedy and cannot be avoided. The options available in responding to the progress of the times and technology are adaptively following it. This adaptive ability can save batik artifacts as part of cultural products. This adaptive ability is essential because the batik user community's demands are also growing, not just covering the body and fashion. The design of ICT use in the batik tulis clothing prototype seeks to highlight additional features, performance, and aesthetics.

Utilization of ICT is beneficial for batik's life force. Support for the advancement of ICT in the Industrial Revolution 4.0, which is increasingly progressing rapidly and sophisticated, should be utilized by batik actors, designers, craftsmen, marketers, and all stakeholders who benefit from batik artifacts as cultural products. The use of this ICT can make batik more and more carried away with the development of the times' spirit (zeitgeist). Thus, in the future era of the Industrial Revolution 5.0, several discoveries such as the ability to change the color of batik clothes automatically, the ability to self-clean on batik (which is being/has been done by the Center for Batikrafts, Yogyakarta), to the ability of automatic batik to be bacteria and viruses, of course very welcomed by the world community.

The creation of batik in this article, which is sustainable design and supports security in the form of being connected by GPS (Global Positioning System), storing data, carrying out/record communications, is still a prototype. The downside of creating this creation is that it must be removed when it is about to be cleaned in the laundry. The technology attached to the prototype on the batik tulis clothing is still not ready for the wet washing treatment. However, collaborative researchers believe that this creation's idea can be realized in a short time and can be used by people around the world.

\section{REFERENCES}

Basadur, M. Gelade, G. 2014. Creative Problem-Solving Process Styles, Cognitive Work Demands, and Organizational Adaptability. Journal of Applied Behavioral Science, 50(1), 80-115.

Dryden, G., Voss, J. 1999. The Learning Revolution : To Change the Way the World Learn, The Learning web, Torrence, US. http:www.thelearningweb.net.

Farid, Muhammad Nur. 2012. Peranan Muatan Lokal Materi Batik tulis Lasem Sebagai Bentuk Peles-tarian Budaya Lokal. Komunitas. Vol 4.1.2012. 90-121.

Gaspersz, V. 2002. Pedoman Implementasi Program Six Sigma. Jakarta: Gramedia Pustaka Utama.

https://ich.unesco.org/en/RL/indonesian-batik-00170, downloaded on 9th September 2020

Iedarwati, Pradewi. 2017. Entrepreneurial Characteristics of Betawi Batik women Activists. Journal of Entrepreneur and Entrepreneurship, Vol. 6, No. 1, March 2017, 17-24. ISSN 2302-1802 print / ISSN 2580-9393 online.

Kharismawati, Mery. 2017. Baju Batik sebagai Omiyage: Studi Kasus Pada Mahasiswa Jepang Yang Pernah Belajar di UGM Tahun 20019-2017. Izumi, Volume 6, No 2, 2017e-ISSN: 502-3535, p-ISSN: 2338-249X

Mandegani, G.B., Setiawan, J., Haerudin, A., Atika, V. 2018. Persepsi Kualitas Batik tulis. Dinamika Kerajinan dan Batik. Majalah Ilmiah, 35(2), 75-84.

Mawardi, I. 2012. ICT (Information and Communication Technology) sebagai Wahana Transformasi Pendidikan. Tarbiyatuna; Jurnal Penelitian dan Pendidikan Islam, 3(1), 99-114. 
Murwanti, A. 2016. Penciptaan Desain Berbasis Praktik Eksperimental Sebagai Penelitian Ilmiah. UL-TIMART Jurnal Komunikasi Visual, 6(2), 7-18.

Poon, S.T.F. 2017. The Journey to Revival: Thriving Revolutionary Batik Design and Its Potential in Contemporary Lifestyle and Fashion. International Journal of History and Cultural Studies (IJHCS), 3(1), $48-59$.

Prasetyaningtyas. 2011. Perkembangan Motif dan Warna Batik Mega Mendung di Kawasan Sentra Batik Trusmi, Cirebon, Jawa Barat. Skripsi, Program Studi Pendidikan Seni Kerajinan, Fakultas Bahasa dan Seni, Universitas Negeri Yogyakarta.

Prasetyo, B., Trisyanti, U. 2018. Revolusi Industri 4.0 dan Tantangan Perubahan Sosial. Prosiding SE-MATEKSOS 3, Strategi Pembangunan Nasional Menghadapi Revolusi Industri 4.0.

Rosyadi, S. 2018. Revolusi Industri 4.0: Peluang dan Tantangan Bagi Alumni Universitas Terbuka. https://www.researchgate.net/publication/324220813_REVOLUSI_INDUSTRI_40\# fullTextFileContent Schwab, K. 2017. The Fourth Industrial Revolution. New York: Crown Business. 